\title{
BEBAN DAN DISIPLIN KERJA BERPENGARUH TERHADAP KINERJA AWAK KAPAL NEGARA ANDROMEDA
}

\author{
Oleh : \\ Muhammad Deni \\ Politeknik Darussalam Palembang \\ Jl. Basuki Rahmat Kemuning Palembang 30151
}

\begin{abstract}
The purpose of this study was to determine the influence of work load and work discipline to performance of Crews Ship of the country Andromeda. Population of this study as many as 15 crews. The results of calculations using SPSS, showed that: $R^{2}$ of $0.349(37.4 \%)$, illustrates that the performance of crews $(Y)$, can be explained by all independent variables $34.9 \%$, while the remaining $65.1 \%$, can be explained by other factors, which are not included in this study. From the result of hypothesis $F$ test, obtained value of $F_{\text {count }}(6.243)>0.05$, means that there is the influence of work load and work discipline together to crew performance. While the results of the hypothesis $t$ test, both of two variables there are no influence of them to performance
\end{abstract}

Keywords : work load, work discipline, performance

\begin{abstract}
ABSTRAK
Tujuan dari penelitian ini adalah untuk mengetahui pengaruh beban kerja dan disiplin kerja terhadap kinerja awak Kapal Negara Andromeda. Populasi penelitian ini sebanyak 15 awak. Hasil perhitungan dengan menggunakan SPSS, menunjukkan bahwa: $\mathrm{R}^{2}$ sebesar 0,349 (37,4\%), menggambarkan bahwa kinerja awak kapal (Y), dapat dijelaskan oleh semua variabel independen 34,9\%, sedangkan sisanya 65,1\%, dapat dijelaskan oleh faktor lain yang tidak termasuk dalam penelitian ini. Dari hasil uji hipotesis F, diperoleh nilai Fhitung $(6,243)>0,05$, berarti ada pengaruh beban kerja dan disiplin kerja terhadap kinerja awak kapal. Sedangkan hasil uji hipotesis t, kedua variabel tersebut tidak berpengaruh terhadap kinerja
\end{abstract}

\section{Kata kunci: beban kerja, disiplin kerja, kinerja}

\section{PENDAHULUAN}

Setiap organisasi didirikan karena mempunyai tujuan yang ingin dicapai. Dalam mencapai tujuannya tersebut organisasi dipengaruhi oleh perilaku dan sikap orang-orang yang terdapat didalamnya. Keberhasilan organisasi tergantung kepada kemampuan 
karyawan dalam mengoperasikan unit-unit kerja yang terdapat dalam organisasi. Apabila suatu organisasi mampu mencapai tujuan yang telah ditetapkan maka dapat dikatakan bahwa organisasi tersebut efektif.

Sumber daya didefinisikan sebagai alat untuk mencapai tujuan atau kemampuan untuk memperoleh keuntungan dengan cara mengelolanya. Menurut Terry ( dalam Herujito, 2001 : 6), sumber daya atau aset yang wajib dimiliki setiap organisasi untuk mencapai tujuan dapat dikatagorikan atas 6 tipe yang disingkat $6 \mathrm{M}$, yaitu: 1) Man (manusia); 2) Money (financial); 3) Material (fisik); 4) Machine (teknologi); 5) Method (metode); dan 6) Market (pasar).

Aset yang paling penting yang harus dimiliki oleh organisasi dan harus diperhatikan dalam manajemen adalah sumber daya manusia. Manusia merupakan elemen yang mengerakan sumber daya lainnya, membuat tujuan, mengadakan inovasi, dan mencapai tujuan organisasi. Betapapun pentingnya atau canggihnya teknologi, metode, ataupun financial, faktor manusia tetap merupakan faktor yang paling menentukan seluruh gerak dan kegiatan organisasi ke arah pencapaian tujuan.

Sumber daya manusia (SDM) dalam pembangunan berperan sebagai penggerak dan pelaksana pembangunan karena manusialah yang mempunyai kemampuan berfikir untuk selalu maju. Apalagi perkembangan zaman dan era globalisasi yang begitu cepat yang tak terpisahkan dari gelombang reformasi, mengharuskan sumber daya manusia memiliki kompetensi yang mampu mewujudkan prinsip good governance dalam pembangunan. SDM pembangunan dituntut untuk mampu mewujudkan dan mengartikulasikan aspirasi dan kebutuhan masyarakat, dan merumuskannya ke dalam kebijakan dan perencanaan, serta mengimplementasikannya.

Sumber daya manusia dalam suatu dinas atau instansi milik pemerintah memiliki peranan yang sangat strategis dalam mencapai suatu tujuan, namun halitu sangat tergantung pada pola pembinaan yang tepat untuk mengelola sumber daya manusia yang ada sehingga dapat mempengaruhi efisiensi dan efetivitas pencapaian tujuan organisasi. Menurut Gomes (2003:14) agar sumber daya manusia yang dimiliki oleh suatu organisasi dapat memberikan kontribusi yang maksimal, maka mutu dan kualitas sumber daya manusia itu perlu dikembangkan sesuai dengan bidang dan keahlian. 
Banyak hal yang harus dipenuhi atau dimiliki oleh sumber daya manusia untuk menghadapi tantangan dalam pembangunan. Berdasarkan hal itulah program peningkatan sumber daya manusia menjadi unsur yang penting dari fungsi manajemen dalam menjalankan kepemerintahan atau pelaksanaan tugas pembangunan. Jika SDM tidak dikelola secara baik, efektivitasnya akan merosot lebih cepat daripada sumber daya lainnya. SDM mempunyai imbas yang lebih besar terhadap efektivitas organisasional dibandingkan sumber daya yang lain. Terlebih di era seperti sekarang, pengelolaan SDM akan semakin meningkat pada semua jenis dan jenjang organisasi, terutama organisasi publik sebagai konsekuensi dari perubahan kehidupan suatu negara yang lebih maju dan demokratis.

Kinerja menurut Mangkunegara (2005 : 67) adalah hasil kerja secara kualitas dan kuantitas yang dicapai oleh seseorang pegawai dalam melaksanakan tugasnya sesuai dengan tanggung jawab yang diberikan kepadanya. Kemudian menurut Sulistiyani (2003 : 223) kinerja seseorang merupakan kombinasi dari kemampuan, usaha dan kesempatan yang dapat dinilai dari hasil kerjanya. Hasibuan (2003:34) mengemukakan kinerja (prestasi kerja) adalah suatu hasil kerja yang dicapai seseorang dalam melaksanakan tugas tugas yang dibebankan kepadanya yang didasarkan atas kecakapan, pengalaman dan kesungguhan serta waktu.

Beban kerja seseorang sudah ditentukan dalam bentuk standar kerja perusahaan menurut jenis pekerjaannya (Mangkunegara, 2005). Beban kerja yang dibebankan kepada karyawan dapat terjadi dalam tiga kondisi. Pertama, beban kerja sesuai standar. Kedua, beban kerja yang terlalu tinggi (over capacity). Ketiga, beban kerja yang terlalu rendah (under capacity). Beban kerja yang terlalu berat atau ringan akan berdampak terjadinya inefisiensi kerja. Beban kerja yang terlalu ringan berarti terjadi kelebihan tenaga kerja. Kelebihan ini menyebabkan organisasi harus menggaji jumlah karyawan lebih banyak dengan produktifitas yang sama sehingga terjadi inefisiensi biaya. Sebaliknya, jika terjadi kekurangan tenaga kerja atau banyaknya pekerjaan dengan jumlah karyawan yang dipekerjakan sedikit, dapat menyebabkan keletihan fisik maupun psikologis bagi karyawan. Akhirnya karyawan pun menjadi tidak produktif karena terlalu lelah. 
SDM merupakan salah satu komponen sumber daya organisasi atau intitusi sebagai penggerak dan penentu diharapkan dapat dijadikan sebagai motor bagi SDM yang lain. Oleh karena itu berhasil atau tidaknya suatu organisasi atau intitusi akan ditentukan oleh faktor manusia atau karyawan dalam mencapai tujuan organisasi.

Kapal Negara Andromeda merupakan Unit Pelaksanaan Teknis (UPT) Direktorat Jendral Perhubungan Laut dibidang kenavigasian yang menyelenggarakan fasilitas keselamatan pelayaran di Wilayah Perairan Provinsi Sumatera Selatan, Jambi dan Bangka Belitung. Kawasan kerja Distrik Navigasi Kelas I Palembang tergolong alur lintas yang ramai dan sibuk.

Awak KN Andromeda yang merupakan salah satu fasilitas pemerintah memiliki tugas mulia mengatur lalu lintas di perariran. Demi mendukung tugas mulia tersebut, efisiensi dan efektifitas organisasi mutlak harus diwujudkan dan dipelihara. Hal ini dikarenakan ketidakefisienan akan menyebabkan turunnya produktivitas organisasi dan mengancam pelaksanaan pencapaian tujuan mulia Distrik Navigasi. Hal inilah yang kemudian melatarbelakangi pentingnya melakukan analisis beban kerja dan disiplin kerja di KN Andromeda. Berdasarkan keadaan di atas tujuan dilakukannya penelitian ini adalah untuk mengetahui pengaruh beban kerja dan disiplin kerja terhadap kinerja awak KN Andromeda.

\section{TINJAUAN PUSTAKA}

\section{Kinerja}

Kinerja menurut Mangkunegara (2005:67), adalah hasil kerja secara kualitas dan kuantitas yang dicapai oleh seorang pegawai dan melaksanakan tugasnya sesuai dengan tanggung jawabnya yang diberikan kepadanya. Kinerja dalam hal ini menunjukan hasil kerja yang dicapai seseorang setelah melaksanakan tugas pekerjaan yang dibebankan oleh organisasi. Kinerja dapat dicapai dengan baik apabila pegawai mampu bekerja sesuai dengan standar penilaian yang ditetapkan organisasi.

Kinerja pada dasarnya adalah apa yang dilakukan atau tidak dilakukan karyawan (Mathis dan Jackson (2002:78). Menurut Mahsun (2006:25) kinerja (performance) adalah gambaran mengenai tingkat pencapaian pelaksanaan suatu 
kegiatan/program/kebijakan dalam mewujudkan sasaran, tujuan, misi dan visi organisasi yang tertuang dalam strategic planning organisasi.

Mangkunegara (2005:67). Ada beberapa faktor yang mempengaruhi pencapaian kinerja, yaitu:

1. Faktor Kemampuan (ability)

Secara psikologis, kemampuan awak kapalterdiri dari kemampuan potensi (IQ) dan kemampuan reality (knowledge + skill).

Menurut Siswanto (2006:236), kemampuan meliputi beberapa hal, yaitu:

a. Kualitas kerja (quality of work)

b. Kuantitas kerja (quantity of work)

c. Pengetahuan tentang pekerjaan (knowledge of job)

d. Kerja sama (coorperation)

e. Pengambilan keputusan (judgement)

2. Faktor Motivasi (Motivation)

Motivasi terbentuk dari sikap seseorang pegawai dalam menghadapi situasi kerja. Motivasi merupakan kondisi yang menggerakan diri pegawai yang terarah untuk mencapai tujuan organisasi. Menurut Mangkunegara (2005:68) berpendapat bahwa ada hubungan positif antara motif berprestasi dengan pencapaian kerja. Motif berprestasi adalah suatu dorongan dalam diri pegawai untuk melakukan suatu kegiatan atau tugas dengan sebaik-baiknya agar mampu mencapai kinerja yang maksimal.

Jadi dapat disimpulkan bahwa kinerja dapat dicapai apabila seseorang mempunyai kemampuan dalam bidang yang dia tekuni serta memiliki motivasi untuk melaksanakan pekerjaan yang dihadapinya.

Menurut Siswanto (2006:41) memperluaskan dimensi kinerja pegawai yang berdasarkan:

1. Quantity work. Jumlah kerja yang dilakukan dalam suatu periode waktu yang ditentukan.

2. Quality of work. Kualitas kerja berdasarkan syarat-syarat kesesuaian dan kesiapannya.

3. Job knowledge. Luasnya pengetahuan mengenai pekerjaan dan keterampilannya.

4. Creativeness. Keaslian gagasan-gagasan yang dimunculkan dan tindakantindakan untuk menyelesaikan persoalan-persoalan yang timbul.

Ada beragam kriteria yang digunakan dalam pengukuran kinerja pegawai.

Bernadin dan Russel (2000), mengajukan enam kriteria untuk mengukur kinerja, yaitu :

a. Kualitas kerja, merupakan tingkat sejauh mana hasil pelaksanaan kegiatan mendekati kesempurnaan atau mendekati tujuan yang diharapkan

b. Kuantitas kerja, merupakan jumlah yang dihasilkan jumlah rupiah, jumlah unit, jumlah siklus kegiatan yang diselesaikan 
c. Waktu yang dibutuhkan, merupakan tingkat sejauh mana suatu kegiatan diselesaikan pada waktu yang dikehendaki dengan memperlihatkan koordinasi output orang lain serta waktu yang tersedia untuk kegiatan yang lain

d. Efektivitas sumber daya, merupakan tingkat sejauh mana penggunaan sumber daya organisasi dimaksimalkan untuk mencapai hasil tertinggi, ataupun pengurangan kerugian dari setiap unit penggunakaan sumber daya

e. Kebutuhan terhadap pengawasan, merupakan tingkat sejauh mana seseorang pekerja dapat melaksanakan suatu fungsi pekerjaan tanpa memerlukan pengawasan seorang supervisor untuk mencegah tindakan yang kurang diinginkan

f. Dampak kepribadian, merupakan tingkat sejauh mana karyawan memelihara harga diri, nama baik dan kerjasama diantara rekan kerja dan bawahan.

Kesimpulannya adalah pencapaian kinerja seseorang bahkan suatu kelompok dapat dilihat dan diukur, dengan terpenuhi kriteria-kriteria umum yang sering digunakan seperti kualitas kerja serta kuantitas kerja dan lain sebagainya.

\section{Beban Kerja}

Beban kerja seseorang sudah ditentukan dalam bentuk standar kerja perusahaan menurut jenis pekerjaannya. Apabila sebagian besar karyawan bekerja sesuai dengan standar perusahaan, maka tidak menjadi masalah. Sebaliknya, jika karyawan bekerja di bawah standar maka beban kerja yang diemban berlebih. Sementara jika karyawan bekerja di atas standar, dapat berarti estimasi standar yang ditetapkan lebih rendah dibanding kapasitas karyawan itu sendiri. Kebutuhan SDM dapat dihitung dengan mengidentifikasikan seberapa banyak output perusahaan pada divisi tertentu yang ingin dicapai.

Kemudian hal itu diterjemahkan dalam bentuk lamanya (jam dan hari) karyawan yang diperlukan untuk mencapai output tersebut, sehingga dapat diketahui pada jenis pekerjaan apa saja yang terjadi deviasi negatif atau sesuai standar. Analisis beban kerja sangat erat kaitannya dengan fluktuasi permintaan pasar akan barang dan jasa perusahaan sekaligus dengan pemenuhan SDM yang diperlukan untuk memenuhi permintaan pasar komoditi. Semakin tinggi permintaan pasar terhadap komoditi tertentu, perusahaan akan segera memenuhinya dengan meningkatkan produksinya. Sejalan dengan itu jumlah tenaga kerja yang dibutuhkan semakin banyak (Mangkuprawira, 2003). 
Moekijat dalam Jaya (2008) menyatakan bahwa prosedur yang sering digunakan untuk menentukan berapa jumlah tenaga kerja yang diperlukan adalah dengan menganalisis pengalaman. Catatan-catatan tentang hasil pekerjaan dapatmenunjukkan volume hasil rata-rata yang dicapai oleh setiap tenaga kerja. Rata - rata tersebut selanjutnya dapat digunakan untuk menaksir kebutuhan tenaga kerja.

Beban kerja dapat dihitung melalui metode work sampling. Barnes dalam Nugraheni (2009), menyatakan bahwa work sampling digunakan untuk mengukur aktifitas pegawai dengan menghitung waktu yang digunakan untuk bekerja dan waktu yang tidak digunakan untuk bekerja dalam jam kerja mereka, kemudian disajikan dalm bentuk persentase. Metode work sampling mengamati apa yang dilakukan oleh responden dan informasi yang dibutuhkan dalam penelitian melalui metode ini adalah waktu kegiatan dan kegiatannya bukan siapa yang melakukan kegiatan.

Barnes dalam Nugraheni (2009) menyatakan ada tiga kegunaan utama dari work sampling diantaranya adalah :

1. Activity and Delay Sampling, yaitu untuk mengukur aktifitas dan penundaan aktifitas dari seorang pekerja. Contohnya adalah dengan mengukur persentase seseorang bekerja dan persentase seseorang tidakbekerja.

2. Performance Sampling, yaitu untuk mengukur waktu yang digunakan untuk bekerja, dan waktu yang tidak digunakan untuk bekerja.

3. Work Measurement, untuk menetapkan waktu standar dari suatu kegiatan

Dari berbagai definisi diatas, dapat diambil kesimpulan, beban kerja adalah jumlah pekerjaan yang harus diselesaikan oleh seseorang dalam jangka waktu tertentu. Beban kerja dapat berupa beban fisik maupun mental dapat dipandang dari sudut obyektif dan subyektif.

\section{Disiplin}

Menurut Nitisemito dalam Jaya (2008), masalah kedisiplinan kerja, merupakan masalah yang perlu diperhatikan, sebab dengan adanya kedisiplinan, dapat mempengaruhi efektifitas dan efisiensi pencapaian tujuan organisasi. Sedangkan menurut 
Greenberg dan Baron dalam Jaya (2008), memandang disiplin melalui adanya hukuman. Disiplin kerja, pada dasarnya dapat diartikan sebagai bentuk ketaatan dari perilaku seseorang dalam mematuhi ketentuan-ketentuan ataupun peraturan-peraturan tertentu yang berkaitan dengan pekerjaan, dan diberlakukan dalam suatu organisasi atau perusahaan.

Dilihat dari sisi manajemen, terjadinya disiplin kerja itu akan melibatkan dua kegiatan pendisiplinan :

a. Preventif

Pada pokoknya, dalam kegiatan ini bertujuan untuk mendorong disiplin diri diantara pegawai, agar mengikuti berbagai standar atau aturan sehingga penyelewengan kerja dapat dicegah.

b. Korektif

Kegiatan yang ditujukan untuk menangani pelanggaran terhadap aturan dan mencoba untuk menghindari pelanggaran-pelanggaran lebih lanjut

Perlu disadari bahwa untuk menciptakan disiplin kerja dalam organisasi atau perusahaan dibutuhkan adanya :a. Tata tertib atau peraturan yang jelas; b. Penjabaran tugas dari wewenang yang cukup jelas; c. Tata kerja yang sederhana, dan mudah diketahui oleh setiap anggotadalam organisasi.

Menurut Byars \& Rue dalam Jaya (2008), ada beberapa hal yang dapat dipakai sebagai indikasi tinggi rendahnya kedisplinan kerja karyawan, yaitu : ketepatan waktu, kepatuhan terhadap atasan, peraturan terhadap perilaku terlarang, ketertiban terhadap peraturan yang berhubungan langsung dengan produktivitaskerja. Sedangkan De Cenzo dan Robbins dalam Jaya (2008) mengemukakan tipe permasalahan dalam kedisiplinan, antara lain kehadiran, perilaku dalam bekerja (dalam lingkungan kerja), ketidakjujuran, aktivitas di luar lingkungan kerja.

\section{KERANGKA PEMIKIRAN}

Berdasarkan permasalahan, tujuan penelitian dan landasan teori yang telah dikemukakan diatas maka dapat disederhanakan dalam kerangka pemikiran (skema alur pikir) dari pola hubungan antar variabel sebagai berikut : 


\section{Gambar 1 \\ Kerangka Pemikiran}

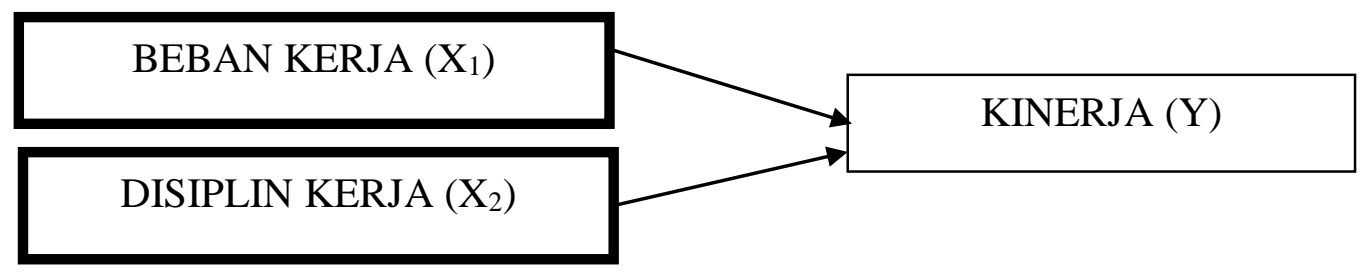

\section{Hipotesis}

a. Diduga beban kerja dan disiplin kerja secara bersama-sama mempunyai pengaruh terhadap kinerja awak KN Andromeda

b. Diduga beban kerja mempunyai pengaruh terhadap kinerja pengaruh terhadap kinerja awak KN Andromeda

c. Diduga disiplin pengaruh terhadap kinerja awak KN Andromeda

\section{METODE PENELITIAN}

Penelitian ini dilakukan pada Kapal Negara Andromeda Departemen Perhubungan Distrik Navigasi Palembang yang berlokasi di Jl. Blinyu No. 9 Boom Baru Palembang. Untuk generalisasi hasil, populasi dan sampel dalam penelitian ini adalah semua awak KN Andromeda yang berjumlah 21 (dua puluh satu) awak.

Variabel independen disini adalah Beban Kerja $\left(\mathrm{X}_{1}\right)$ dan Disiplin kerja $\left(\mathrm{X}_{2}\right)$, diproxy dari kuisioner yang dibagikan kepada awak KN Andromeda, sedangkan variabel dependen disini adalah kinerja pegawai.

Beban kerja adalah keadaan dimana awak kapal dihadapkan pada banyak pekerjaan yang harus dikerjakan dan merasa tidak memiliki kemampuan untuk menyelesaikan pekerjaan tersebut karena standar pekerjaan terlalu tinggi. Beban kerja diukur dengan memodifikasi instrumen yang dikembangkan oleh Tarwaka dalam Nugraheni (2009), menggunakan skala Likert 5 jenjang dari 1 sangat tidak setuju sampai dengan 5 sangat setuju.

Disiplin awak kapal adalah ketaatan seorang awak KN Andromeda terhadap ketentuan yang berlaku dan disepakati bersama secara sukarela dan penuh kesadaran. Disiplin diukur dengan memodifikasi instrumen yang dikembangkan oleh Susilawati (2005), menggunakan skala Likert 5 jenjang dari 1 sangat tidak setuju sampai dengan 5 sangat setuju. 
Kinerja awak kapal yang dimaksud dalam penelitian ini yaitu hasil kerja secara kualitas dan kuantitas yang dicapai oleh seorang awak kapaldan melaksanakan tugasnya sesuai dengan tanggung jawabnya yang diberikan kepadanya. Kinerja dalam hal ini menunjukan hasil kerja yang dicapai seseorang setelah melaksanakan tugas pekerjaan yang dibebankan oleh organisasi. Kinerja awak kapal diukur dengan memodifikasi instrumen yang dikembangkan oleh Bernadin \& Russel (2000) menggunakan skala Linkert 5 jenjang dari 1 sangat tidak setuju sampai 5 sangat setuju.

\section{Teknik Analisis}

Menurut Husein (2005:180) terdapat dua konsep uji kualitas data, yaitu validitas dan reliabelitas, artinya suatu penelitian akan menghasilkan kesimpulan yang bias jika datanya kurang valid dan kurang reliabel. Sebelum data diuji validitas dan reliabilitasnya, terlebih dahulu skala ordinal ditransformasikan ke dalam skala interval.

Uji asumsi klasik bertujuan untuk memastikan bahwa model yang digunakan benar-benar memenuhi asumsi dasar dalam analisis regresi yang meliputi asumsi : data terdistribusi normal, tidak terjadi multikolinearitas, dan tidak terjadi heteroskedastisitas.

Secara simbolik dinyatakan ke dalam model sebagai berikut:

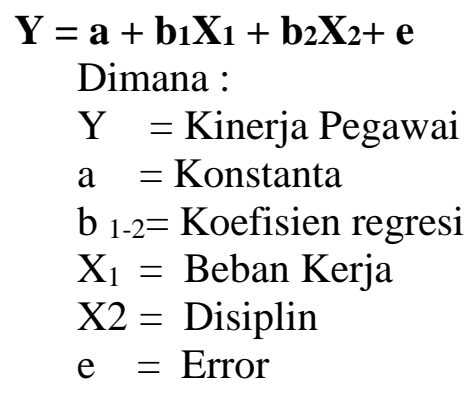

\section{Uji Hipotesis}

Uji-F dan uji-t statistik digunakan untuk mengetahui tingkat signifikansi, variabel yang mempengaruhi (variabel independen) terhadap variabel yang dipengaruhi (variabel dependen) secara serentak dan sebagian. 


\section{Hasil dan Pembahasan}

\section{Deskripsi Data}

Objek dalam penelitian ini adalah awal kapal negara Andromeda. Kuesioner yang didistribusikan kepada awak kapalsebanyak 21 paket. Dari jumlah tersebut yang dikembalikan sebanyak 21 paket, berarti terdapat response rate sebesar 100\%. Setelah dilakukan verifikasi kelengkapan dalam mengisi data, terdapat 6 paket kuesioner yang tidak layak untuk diikutsertakan dalam analisis. Akhirnya total kuesioner yang layak dianalisis berjumlah 15 paket

\section{Karakteristik Jawaban Responden}

1) Variabel Kinerja (Y)

Tabel 1

Rekapitulasi Jawaban Responden Terhadap Variabel Kinerja

\begin{tabular}{|l|c|c|c|c|c|c|c|c|c|c|c|}
\hline \multirow{2}{*}{ No } & \multicolumn{9}{|c|}{ Jawaban } & \multirow{5}{*}{} & \multicolumn{5}{|c|}{ Persentase (\%) } \\
\cline { 2 - 7 } & $\mathbf{1}$ & $\mathbf{2}$ & $\mathbf{3}$ & $\mathbf{4}$ & $\mathbf{5}$ & No & $\mathbf{1}$ & $\mathbf{2}$ & $\mathbf{3}$ & $\mathbf{4}$ & $\mathbf{5}$ \\
\hline Y_1 & 0 & 1 & 2 & 9 & 3 & $\mathbf{1}$ & 0 & 7 & 13 & 60 & 20 \\
\hline Y_2 & 0 & 1 & 4 & 6 & 4 & $\mathbf{2}$ & 0 & 7 & 26.5 & 40 & 26.5 \\
\hline Y_3 & 0 & 2 & 3 & 7 & 3 & $\mathbf{3}$ & 0 & 13 & 20 & 47 & 20 \\
\hline Y_4 & 1 & 1 & 8 & 5 & 0 & $\mathbf{4}$ & 7 & 7 & 53 & 33 & 0 \\
\hline Y_5 & 0 & 1 & 1 & 11 & 2 & $\mathbf{5}$ & 0 & 7 & 7 & 73 & 13 \\
\hline Y_6 & 0 & 1 & 4 & 8 & 2 & $\mathbf{6}$ & 0 & 7 & 27 & 53 & 13 \\
\hline Y_7 & 1 & 1 & 6 & 4 & 3 & $\mathbf{7}$ & 7 & 7 & 40 & 26 & 20 \\
\hline Y_8 & 0 & 1 & 5 & 7 & 2 & $\mathbf{8}$ & 0 & 7 & 33 & 47 & 13 \\
\hline Y_9 & 0 & 1 & 4 & 7 & 3 & $\mathbf{9}$ & 0 & 7 & 26 & 47 & 20 \\
\hline
\end{tabular}

\section{Sumber : Hasil Rekapitulasi Jawaban Variabel Kinerja 2017, diolah}

Berikut analisis jawaban responden berdasarkan tabel di atas untuk masingmasing item pertanyaan kuesioner:

Y_1 "Setiap Awak kapal Memahami Lingkup Pekerjaan", terlihat bahwa responden menjawab ke arah positif, yaitu 10 orang $(60 \%)$ menjawab setuju dan 3 orang (20\%) menjawab sangat setuju, kecuali ada 1 orang $(7 \%)$, yang menjawab tidak setuju dan 2 orang (13\%) yang ragu-ragu. Hal ini menggambarkan bahwa mayoritas responden, telah memahami lingkup pekerjaannya masing-masing.

Y_2 "Setiap Awak kapal Memiliki Ketetapan dan Ketelitian Dalam Bekerja", terlihat bahwa responden menjawab ke arah positif, yaitu 6 orang (40\%) menjawab setuju dan 4 orang (26.5\%) menjawab sangat setuju, kecuali ada 4 orang (26.5\%), yang 
menjawab ragu-ragu dan 1 orang (7\%) yang menjawab tidak setuju. Hal ini menggambarkan bahwa mayoritas responden, memiliki ketetapan dan teliti dalam menyelesaikan pekerjaan.

Y_3 "Setiap Awak kapal Memiliki Keterampilan yang Baik", terlihat bahwa responden menjawab ke arah positif, yaitu 7 orang (47\%) menjawab setuju dan 3 orang (20\%) menjawab sangat setuju, kecuali ada 2 orang (13\%), yang menjawab tidak setuju dan 3 orang (20\%) menjawab ragu-ragu. Hal ini menggambarkan bahwa mayoritas responden, terampil dalam bekerja.

Y_4 "Pekerjaan Yang Dihasilkan para Awak Kapal Melebihi Target Yang Ditetapkan", terlihat bahwa responden menjawab ragu-ragu yaitu 8 orang (53\%). Yang menjawab setuju sebanyak 5orang (33\%), kecuali ada 1 orang (7\%), yang menjawab tidak setuju, serta 1 orang (7\%) yang menjawab sangat tidak setuju. Hal ini menggambarkan bahwa mayoritas responden, meragukan kalau pekerjaan yang dihasilkan mereka melebihi target yang ditetapkan.

Y_5 "Pekerjaan Yang Dihasilkan Para Awak kapal Mengalami Peningkatan", terlihat bahwa responden menjawab ke arah positif, yaitu 11 orang (73\%) menjawab setuju dan 2 orang (13\%) menjawab sangat setuju, kecuali ada 1 orang (7\%), yang menjawab tidak setuju dan 1 orang (7\%) menjawab ragu-ragu. Hal ini menggambarkan bahwa mayoritas responden mengalami peningkatan dalam menghasilkan pekerjaannya.

Y_6 "Beban Kerja Yang Diterima Awak kapal Sudah Sesuai Dengan Kemampuannya", terlihat bahwa responden menjawab ke arah positif, yaitu 8 orang (53\%) menjawab setuju dan 2 orang (13\%) menjawab sangat setuju, kecuali ada 1 orang (7\%), yang menjawab tidak setuju dan 4 orang (27\%) menjawab ragu-ragu. Hal ini menggambarkan bahwa mayoritas responden, menyadari bahwa beban kerja yang mereka terima sedah sesuai dengan kemampuan masing-masing.

Y_7 "Kinerja Awak KN Andromeda Sangat Profesional", terlihat bahwa responden menjawab ragu-ragu yaitu 6 orang (53\%), 4 orang (26\%) menjawab setuju dan 3 orang (20\%) menjawab sangat setuju, kecuali ada 1 orang $(7 \%)$, yang menjawab tidak setuju dan 1 orang (7\%) menjawab sangat tidak setuju. Hal ini menggambarkan bahwa mayoritas responden meragukan kalau awak kapalitu professional.

Y_8 "Pekerjaan Yang Dihasilkan Para Awak kapal Lebih Cepat Dari Yang Dijanjikan", terlihat bahwa semua responden menjawab ke arah positif, yaitu 7 orang (47\%) menjawab setuju dan 2 orang (13\%) menjawab sangat setuju, kecuali ada 5 orang (33\%), yang menjawab ragu-ragu dan 1 orang (7\%) yang menjawab tidak setuju. Hal ini menggambarkan bahwa mayoritas responden, menghasilkan pekerjaan lebih cepat dari yang dijanjikan.

Y_9 “Awak kapal Selalu Tepat Waktu Dalam Masuk dan Keluar Kantor”, terlihat bahwa semua responden menjawab ke arah positif, yaitu 7 orang (47\%) menjawab setuju dan3 orang (20\%) menjawab sangat setuju, kecuali ada 4 orang (26\%), yang menjawab ragu-ragu dan 1 orang (7\%) yang menjawab tidak setuju. Hal ini menggambarkan bahwa mayoritas responden, selalu tepat waktu dalam masuk dan keluar kantor. 
2) Variabel Beban Kerja $\left(X_{1}\right)$

Tabel 2

Rekapitulasi Jawaban Responden Terhadap Variabel Beban Kerja

\begin{tabular}{|c|c|c|c|c|c|c|c|c|c|c|c|}
\hline \multirow[b]{2}{*}{$\mathbf{P}$} & \multicolumn{5}{|c|}{ Jawaban } & \multirow[b]{2}{*}{ No } & \multicolumn{5}{|c|}{ Persentase (\%) } \\
\hline & 1 & 2 & 3 & 4 & 5 & & 1 & 2 & 3 & 4 & 5 \\
\hline $\mathbf{X}_{11} 1$ & 0 & 9 & 4 & 2 & 0 & 1 & 0 & 60 & 27 & 13 & 0 \\
\hline $\mathrm{X}_{1 \_2}$ & 0 & 8 & 4 & 3 & 0 & 2 & 0 & 53 & 27 & 20 & 0 \\
\hline $\mathbf{X}_{1 \_3}$ & 0 & 1 & 5 & 8 & 1 & 3 & 0 & 7 & 33 & 53 & 7 \\
\hline$X_{1} 5$ & 1 & 5 & 5 & 3 & 1 & 4 & 7 & 33 & 33 & 20 & 7 \\
\hline$X_{1 \_} 6$ & 0 & 1 & 2 & 9 & 3 & 5 & 0 & 7 & 13 & 60 & 20 \\
\hline $\mathrm{X}_{1 \_} \mathbf{7}$ & 1 & 6 & 6 & 1 & 1 & 6 & 7 & 40 & 40 & 7 & 6 \\
\hline $\mathrm{X}_{1} \_8$ & 0 & 7 & 3 & 4 & 1 & 7 & 0 & 46 & 20 & 27 & 7 \\
\hline
\end{tabular}

Sumber : Hasil Penelitian 2017, diolah SPSS

Analisis jawaban responden berdasarkan tabel di atas untuk masing-masing item pertanyaan kuesioner adalah sebagai berikut:

$\mathrm{X}_{1}$ 1 "Pekerjaan yang diberikan kepada awak kapal terlalu berat", terlihat bahwa responden menjawab ke arah positif, yaitu 9 orang (60\%) menjawab tidak setuju dan 4 orang (27\%) menjawab ragu-ragu, kecuali ada 2 orang (13\%), yang menjawab setuju. Hal ini menggambarkan bahwa mayoritas responden, merasa tidak setuju kalau beban yang mereka terima saat ini terlalu berat.

$\mathrm{X}_{1}$ 2 "Terlalu banyak pekerjaan yang harus dilakukan", terlihat bahwa responden menjawab ke arah positif, yaitu 8 orang (53\%) menjawab tidak setuju dan 4 orang (27\%) menjawab ragu-ragu, kecuali ada 3 orang (20\%), yang menjawab setuju. Hal ini menggambarkan bahwa mayoritas responden, tidak melalukan banyak pekerjaan.

$\mathrm{X}_{1} \_3$ "Awak kapalselalu dituntut untuk dapat setiap saat mengambil keputusan yang harus tepat", terlihat bahwa responden menjawab ke arah positif, yaitu 8orang (53\%) menjawab setuju dan 1 orang (7\%) menjawab sangat setuju, 5 orang (33\%) menjawab ragu-ragu, kecuali ada 1 orang (7\%), yang menjawab tidak setuju. Hal ini menggambarkan bahwa mayoritas responden, selau tepat dalam pengambilan keputusan.

$\mathrm{X}_{1}$ 5 "Awak kapaldituntut untuk dapat memberikan pelayanan yang berkualitas", terlihat bahwa 5 orang $(33 \%)$ responden menjawab tidak setuju bahkan 1 orang $(7 \%)$ menjawab sangat tidak setuju dan 5 orang (33\%) menjawab ragu-ragu, kecuali ada 3 orang (20\%), yang menjawab setuju dan 1 orang (7\%) menjawab sangat setuju. Hal ini menggambarkan bahwa mayoritas responden, merasa tidak setuju dan raguragu kalau mereka telah memberikan pelayanan yang berkualitas.

$\mathrm{X}_{1 \_} 6$ "Terlalu banyak tuntutan pimpinan", terlihat bahwa responden menjawab ke arah negatif, yaitu 9 orang (60\%) menjawab setuju dan 3 orang (20\%) menjawab sangat setuju, kecuali ada 2 orang (13\%) yang menjawab ragu-ragu dan 1 orang (7\%) 
menjawab tidak setuju. Hal ini menggambarkan bahwa mayoritas responden, menyatakan pimpinan terlalu banyak menuntut.

$\mathrm{X}_{1} 7$ "Awak kapal kurang nyaman terhadap tuntutan pimpinan", terlihat bahwa responden menjawab ke arah positif, yaitu 6 orang (40\%) menjawab tidak setuju dan 1 orang $(7 \%)$ menjawab sangat tidak setuju, 6 orang $(40 \%)$ menjawab raguragu, kecuali ada 1 orang (7\%) yang menjawab setuju dan 1 orang $(6 \%)$ menjawab sangat setuju. Hal ini menggambarkan bahwa mayoritas responden tidak setuju dan ragu-ragu akan tuntutan pimpinan.

$\mathrm{X}_{1} 8$ “Awak kapal jenuh dan bosan dengan tugas yang dibebankan”, terlihat bahwa responden menjawab ke arah positif, yaitu 7 orang (46\%) menjawab tidak setuju dan 3 orang (20\%) menjawab ragu-ragu, kecuali ada 4 orang (27\%), yang menjawab 1 orang (7\%) menjawab sangat setuju. Hal ini menggambarkan bahwa mayoritas responden, menikmati pekerjaan mereka

\section{3) Variabel Disiplin Kerja $\left(\mathbf{X}_{2}\right)$}

\section{Tabel 3}

Rekapitulasi Jawaban Responden Terhadap Variabel Disiplin Kerja

\begin{tabular}{|c|c|c|c|c|c|c|c|c|c|c|c|}
\hline \multirow[b]{2}{*}{ No } & \multicolumn{5}{|c|}{ Jawaban } & \multirow[b]{2}{*}{ No } & \multicolumn{5}{|c|}{ Persentase (\%) } \\
\hline & 1 & 2 & 3 & 4 & 5 & & 1 & 2 & 3 & 4 & 5 \\
\hline $\mathbf{X}_{2 \_} \mathbf{1}$ & 0 & 1 & 1 & 10 & 3 & 1 & 0 & 7 & 7 & 66 & 20 \\
\hline$X_{2 \_} 2$ & 1 & 1 & 1 & 10 & 2 & 2 & 7 & 7 & 7 & 66 & 13 \\
\hline $\mathrm{X}_{2} 3$ & 0 & 0 & 1 & 12 & 2 & 3 & 0 & 0 & 7 & 80 & 13 \\
\hline$X_{2} 4$ & 0 & 0 & 1 & 12 & 2 & 4 & 0 & 0 & 7 & 80 & 13 \\
\hline$X_{2} 5$ & 1 & 1 & 1 & 11 & 1 & 5 & 7 & 7 & 7 & 72 & 7 \\
\hline$X_{2} 6$ & 0 & 1 & 1 & 10 & 3 & 6 & 0 & 7 & 7 & 66 & 20 \\
\hline $\mathbf{X}_{2 \_} 7$ & 1 & 1 & 1 & 10 & 2 & 7 & 7 & 7 & 7 & 66 & 13 \\
\hline
\end{tabular}

\section{Sumber : Hasil Rekapitulasi Jawaban Variabel Disiplin 2017, diolah}

$\mathrm{X}_{2} 1$ “Aturan yang jelas menjadi pedoman untuk menyelesaikan tugas yang dibebankan", terlihat bahwa responden menjawab ke arah positif, yaitu 10 orang (66\%) menjawab setuju dan 3 orang (20\%) menjawab sangat setuju, kecuali ada 1 orang (7\%) yang menjawab ragu-ragu dan 1 orang (7\%) menjawab tidak setuju. Hal ini menggambarkan bahwa mayoritas responden, menyelesaikan tugas berdasarkan aturan yang jelas.

$\mathrm{X}_{2} 2$ "Mentaati aturan dan prosedur kerja yang telah digariskan oleh organisasi walaupun tidak sesuai dengan pendapat saya", terlihat bahwa responden menjawab ke arah positif, yaitu 10 orang (66\%) menjawab setuju dan 2 orang (13\%) menjawab sangat setuju, kecuali ada 1 orang (7\%) yang menjawab ragu-ragu, 1 orang (7\%) menjawab tidak setuju dan 1 orang $(1 \%)$ yang menjawab sangat tidak setuju. Hal ini menggambarkan bahwa mayoritas responden, taat aturan.

$\mathrm{X}_{2} 3$ "Tugas dan pekerjaan yang awak kapal selesaikan harus mengikuti prosedur kerja yang telah ditentukan", terlihat bahwa responden menjawab ke arah positif, yaitu 
12 orang (80\%) menjawab setuju dan 2 orang (13\%) menjawab sangat setuju, kecuali ada 1 orang (7\%) yang menjawab ragu-ragu. Hal ini menggambarkan bahwa mayoritas responden, taat prosedur.

$\mathrm{X}_{2} 4$ "Awak kapal menyelesaikan tugas sesuai dengan uraian tugas yang diberikan kepadanya", terlihat bahwa responden menjawab ke arah positif, yaitu 12 orang (80\%) menjawab setuju dan 2 orang (13\%) menjawab sangat setuju, kecuali ada 1 orang $(7 \%)$ yang menjawab ragu-ragu. Hal ini menggambarkan bahwa mayoritas responden, tugas selesai sesuai dengan uraian tugas

$\mathrm{X}_{2} 5$ "Awak kapal menghormati aturan kerja dari atasan walaupun tidak sesuai dengan hati nuraninya", terlihat bahwa responden menjawab ke arah positif, yaitu 11 orang $(72 \%)$ menjawab setuju dan 1 orang $(7 \%)$ menjawab sangat setuju, 1 orang (7\%) menjawab ragu-ragu, kecuali ada 1 orang $(7 \%)$ yang menjawab tidak setuju dan 1 orang $(7 \%)$ menjawab sangat tidak setuju. Hal ini menggambarkan bahwa mayoritas responden, bekerja secara profesional

$\mathrm{X}_{2} 6$ "Keakuratan dalam melaksanakan pekerjaan diprioritaskan", terlihat bahwa responden menjawab ke arah positif, yaitu 10 orang (66\%) menjawab setuju dan 3 orang $(20 \%)$ menjawab sangat setuju, 1 orang $(7 \%)$ menjawab ragu-ragu, kecuali ada 1 orang $(7 \%)$ yang menjawab tidak setuju. Hal ini menggambarkan bahwa mayoritas responden, bekerja secara akurat.

$\mathrm{X}_{2} 7$ "Awak kapal menggunakan alat kapal untuk membantu menyelesaikan tugas kapal", terlihat bahwa semua responden menjawab ke arah positif, yaitu 10 orang (66\%) menjawab setuju dan 2 orang (13\%) menjawab sangat setuju, 1 orang (7\%) menjawab ragu-ragu, kecuali ada 1 orang (7\%) yang menjawab tidak setuju dan 1 orang $(7 \%)$ menjawab sangat tidak setuju. Hal ini menggambarkan bahwa mayoritas responden, alat kapal sangat berguna untuk menunjang tugas awak kapal.

\section{Pengujian Kualitas Data \\ Pengujian Validitas Data}

Data yang diuji validitasnya adalah Kinerja (Y), Beban Kerja $\left(\mathrm{X}_{1}\right)$, Displin $\left(\mathrm{X}_{2}\right)$. Sedangkan nilai $\mathrm{R}_{\text {tabel }}$ dengan taraf nyata $(\alpha)=5 \%$ dan $\mathrm{n}=50$, yaitu 0,279 . Sementara itu, menurut Sekaran (2010:90), jika $\mathrm{R}_{\text {hitung }} \geq \mathrm{R}_{\text {tabel }}$ Valid, sedangkan jika $\mathrm{R}_{\text {hitung }} \leq \mathrm{R}_{\text {tabel }}$, tidak valid, maka :

Tabel 4 Hasil Uji Validitas

Variabel Kinerja (Y)

\begin{tabular}{|c|c|c|c|c|}
\hline No & Item & $\begin{array}{c}\text { Corrected Item } \\
\text { Total Correlation }\end{array}$ & $\begin{array}{c}\text { Rtabel } \\
(\boldsymbol{\alpha}=\mathbf{5 \%})\end{array}$ & $\begin{array}{c}\text { Hasil } \\
\text { Validitas }\end{array}$ \\
\hline 1 & Y_1 & 0,598 & 0,279 & Valid \\
\hline 2 & Y_2 & 0,629 & 0,279 & Valid \\
\hline 3 & Y_3 & 0,768 & 0,279 & Valid \\
\hline 4 & Y_4 & 0,724 & 0,279 & Valid \\
\hline
\end{tabular}




\begin{tabular}{|l|l|l|l|l|}
\hline 5 & Y_5 & 0,600 & 0,279 & Valid \\
\hline 6 & Y_6 & 0,718 & 0,279 & Valid \\
\hline 7 & Y_7 & 0,718 & 0,279 & Valid \\
\hline 8 & Y_8 & 0,806 & 0,279 & Valid \\
\hline 9 & Y_9 & 0,331 & 0,279 & Valid \\
\hline
\end{tabular}

Sumber : data diolah, 2017

Tabel 5 Hasil Uji Validitas

Variabel Beban Kerja ( $\left.\mathbf{X}_{1}\right)$

\begin{tabular}{|c|c|c|c|c|}
\hline No & Item & $\begin{array}{c}\text { Corrected Item } \\
\text { Total Correlation }\end{array}$ & $\begin{array}{c}\text { Rtabel } \\
(\boldsymbol{\alpha}=\mathbf{5 \%})\end{array}$ & $\begin{array}{c}\text { Hasil } \\
\text { Validitas }\end{array}$ \\
\hline 1 & X1_1 & 0,478 & 0,279 & Valid \\
\hline 2 & X1_2 & 0,321 & 0,279 & Valid \\
\hline 3 & X1_3 & 0,393 & 0,279 & Valid \\
\hline 4 & X1_5 & 0,485 & 0,279 & Valid \\
\hline 5 & X1_6 & 0,279 & 0,279 & Valid \\
\hline 6 & X1_7 & 0,678 & 0,279 & Valid \\
\hline 7 & X1_8 & 0,507 & 0,279 & Valid \\
\hline
\end{tabular}

Sumber : data diolah, 2017

Tabel 6 Hasil Uji Validitas

Variabel Disiplin Kerja

\begin{tabular}{|c|c|c|c|c|}
\hline No & Item & $\begin{array}{c}\text { Corrected Item } \\
\text { Total Correlation }\end{array}$ & $\begin{array}{c}\text { Rtabel } \\
(\boldsymbol{\alpha}=\mathbf{5 \%})\end{array}$ & $\begin{array}{c}\text { Hasil } \\
\text { Validitas }\end{array}$ \\
\hline 1 & $\mathrm{X} 2 \_2$ & 0,578 & 0,279 & Valid \\
\hline 2 & $\mathrm{X} 2 \_3$ & 0,567 & 0,279 & Valid \\
\hline 3 & $\mathrm{X} 2 \_4$ & 0,499 & 0,279 & Valid \\
\hline 4 & $\mathrm{X} 2 \_5$ & 0,522 & 0,279 & Valid \\
\hline 5 & $\mathrm{X} 2 \_6$ & 0,331 & 0,279 & Valid \\
\hline 6 & $\mathrm{X} 2 \_7$ & 0,700 & 0,279 & Valid \\
\hline 7 & $\mathrm{X} 2 \_8$ & 0,337 & 0,279 & Valid \\
\hline
\end{tabular}

Sumber : data diolah, 2017

Pengujian Reabilitas Data

Tabel 7 Hasil Uji Reabilitas

\begin{tabular}{|c|l|c|c|c|}
\hline No & \multicolumn{1}{|c|}{ Variabel } & $\begin{array}{c}\text { Cronbach } \\
\text { Alpha }\end{array}$ & $\begin{array}{c}\text { Nilai Alpha } \\
(\boldsymbol{\alpha = 5 \%})\end{array}$ & $\begin{array}{c}\text { Hasil Uji } \\
\text { Reabilitas }\end{array}$ \\
\hline 1 & Kinerja $(\mathrm{Y})$ & 0,890 & 0,600 & Reliabel \\
\hline 3 & Beban Kerja $\left(\mathrm{X}_{1}\right)$ & 0,733 & 0,600 & Reliabel \\
\hline 4 & Disiplin $\left(\mathrm{X}_{2}\right)$ & 0,752 & 0,600 & Reliabel \\
\hline
\end{tabular}

Sumber : data diolah, 2017 


\section{Pengujian Asumsi Klasik}

Sebelum penulis melakukan pengujian pengaruh variabel bebas terhadap variabel terikat, maka berikut ini penulis terlebih dahulu akan melakukan pengujian asumsi klasik, sebagai berikut:

\section{Normalitas}

\section{Tabel 8}

\begin{tabular}{|c|c|c|c|c|}
\hline & & $\bar{Y}$ & $\mathrm{X} 1$ & $\mathrm{X} 2$ \\
\hline \multicolumn{2}{|l|}{$\mathrm{N}$} & 15 & 15 & 15 \\
\hline \multirow{2}{*}{ Normal Parameters ${ }^{a, b}$} & Mean & 26,4914 & 17,4884 & 22,3633 \\
\hline & Std. Deviation & 5,94138 & 3,84042 & 3,83000 \\
\hline \multirow{3}{*}{$\begin{array}{l}\text { Most Extreme } \\
\text { Differences }\end{array}$} & Absolute & ,096 & , 179 & ,293 \\
\hline & Positive &, 060 & 179 & ,293 \\
\hline & Negative &,- 096 &,- 070 &,- 207 \\
\hline \multicolumn{2}{|l|}{ Kolmogorov-Smirnov Z } & ,681 & 1,266 & 2,074 \\
\hline \multicolumn{2}{|l|}{ Asymp. Sig. (2-tailed) } & ,742 & ,081 & ,366 \\
\hline
\end{tabular}

Sumber : data diolah, 2017

Berdasarkan tabel di atas:

a. Variabel Kinerja : Nilai Asymp sig hitung atau yang berasal dari data sebesar 0,743 $>0,05$ maka, $\mathrm{H}_{0}$ diterima dan $\mathrm{H}_{1}$ ditolak (data berdistribusi normal)

b. Variabel Beban Kerja : Nilai Asymp sig hitung atau yang berasal dari data sebesar 0,081 > 0,05 maka, $\mathrm{H}_{0}$ diterima dan $\mathrm{H}_{1}$ ditolak (data berdistribusi normal)

c. Variabel Disiplin : Nilai Asymp sig hitung atau yang berasal dari data sebesar 0,366 $>0,05$ maka, $\mathrm{H}_{0}$ diterima dan $\mathrm{H}_{1}$ ditolak (data berdistribusi normal)

\section{Multikolinieritas}

\section{Tabel 9}

\section{Uji Multikolinearitas}

\begin{tabular}{|c|l|c|c|}
\hline \multirow{2}{*}{ No } & \multicolumn{1}{|c|}{ Variabel } & \multicolumn{2}{|c|}{ Collinearity Statistics } \\
\cline { 3 - 4 } & & Tolerance & VIF \\
\hline 1. & Beban Kerja (X1) & 0,865 & 1,156 \\
\hline 2. & Disiplin (X2) & 0,523 & 1,911 \\
\hline
\end{tabular}

Sumber : Data primer diolah, SPSS Ver. 2.0, 2017

Berdasarkan tabel diatas dapat diketahui bahwa, masing-masing variabel independen memiliki VIF tidak lebih dari 10 dan nilai Tolerance tidak kurang dari 0,1 , maka dapat dinyatakan model regresi linear berganda terbebas dari asumsi klasik statistik dan dapat digunakan dalam penelitian. 


\section{Heteroskedastisitas}

Output SPSS pada gambar Scatterplot menunjukkan penyebaran titik-titik sebagai berikut : a) Titik - titik data menyebar di atas dan di bawah atau sekitar angka 0; b) Titik - titik data tidak mengumpul hanya di atas atau dibawah saja; c) Penyebaran titik - titik data tidak membentuk pola bergelombang melebar kemudian menyempit dan melebar kembali; d) Penyebaran titik - titik tidak berpola, maka dapat disimpulkan bahwa model regresi linier berganda terbebas dari asumsi klasik heteroskedastisitas dan layak digunakan dalam penelitian.

Dari hasil pengujian asumsi dasar ternyata data yang digunakan dalam penelitian ini dinyatakan tidak mengandung multikolinieritas, heteroskedastisitas, serta normalitas data yang normal. Dengan telah selesainya pengujian asumsi dasar regresi di atas, maka dapat disimpulkan bahwa data yang dipergunakan, layak untuk dianalisis dengan analisis regresi.

\section{Model dan Rancangan Uji Hipotesis}

Untuk menjawab permasalahan tentang bagaimana pengaruh beban kerja dan disiplin terhadap kinerja, maka berikut ini akan dilakukan analisis dengan menggunakan :

\section{Analisis Regresi Berganda}

Tabel 10

Hasil Uji Regresi Berganda

Coefficients $^{\mathrm{a}}$

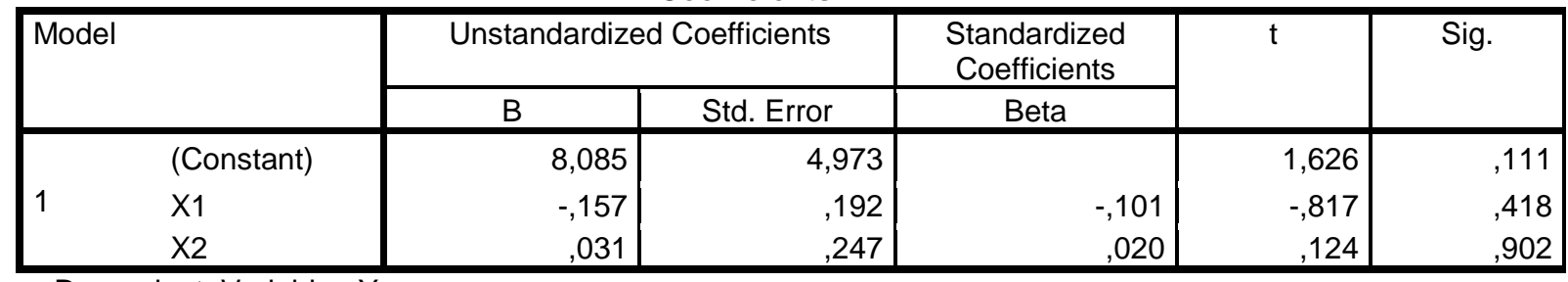

a. Dependent Variable : $Y$

Dari hasil regresi berganda dengan menggunakan bantuan program SPSS for Windows versi 2.0 pada variabel beban kerja $\left(\mathrm{x}_{1}\right)$ dan displin $\left(\mathrm{X}_{2}\right)$ secara parsial terhadap kinerja $(\mathrm{Y})$ dapat digambarkan persamaan regresi sebagai berikut : $\mathbf{Y}=\mathbf{8 , 0 8 5}-\mathbf{0 , 1 5 7} \mathbf{X}_{\mathbf{1}}$ $+\mathbf{0 , 0 3 1} \mathrm{X}_{2}$ 


\section{Uji Koefisien Determinan}

Tabel 11

Hasil Uji Koefisien Determinan Model Summary

\begin{tabular}{|l|r|r|r|r|}
\hline Model & R & R Square & $\begin{array}{c}\text { Adjusted R } \\
\text { Square }\end{array}$ & $\begin{array}{c}\text { Std. Error of the } \\
\text { Estimate }\end{array}$ \\
\hline 1 &, $644^{\mathrm{a}}$ &, 415 &, 349 & 4,79553 \\
\hline
\end{tabular}

a. Predictors: (Constant), X1, X2

b. Dependent Variable: $Y$

Angka R Square (Angka korelasi atau r yang dikuadratkan) sebesar 0,349. Angka R Square disebut juga koefisien determinan. Besarnya angka koefisien determinan 0,349 atau sama dengan 34,9\%. Angka tersebut berarti, sebesar 34,9\% kinerja awak kapal yang terjadi dapat dijelaskan dengan menggunakan variabel beban kerja dan disiplin sedangkan sebesar $65,1 \%$ dapat dijelaskan oleh faktor-faktor penyebab lainnya. Dengan kata lain besarnya pengaruh variabel beban kerja dan disiplin awak kapal adalah sebesar $34,9 \%$.

\section{Pengaruh Beban Kerja dan Disiplin Secara Bersama-sama Terhadap Kinerja Pegawai}

Untuk menjawab permasalahan tentang bagaimana pengaruh beban kerja $\left(\mathrm{X}_{1}\right)$ dan disiplin $\left(\mathrm{X}_{2}\right)$ secara bersama-sama terhadap kinerja $(\mathrm{Y})$, penulis menggunakan uji hipotesis F sebagai berikut :

Tabel 12

ANOVA $^{\mathrm{a}}$

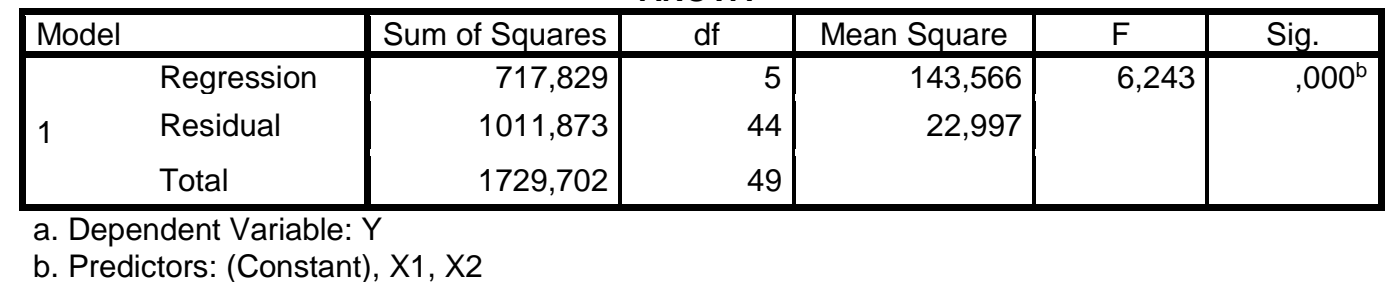

Menurut Priyatno (2010:67), jika $F_{\text {hitung }} \geq 0,05$, maka $\mathrm{H}_{0}$ ditolak dan $\mathrm{H}_{\mathrm{a}}$ diterima, jika $\mathrm{F}_{\text {hitung }}<0,05$, maka $\mathrm{H}_{0}$ diterima $\mathrm{H}_{\mathrm{a}}$ ditolak. Sedangkan taraf nyata $(\alpha)=5 \%$ dengan penyebut $\mathrm{dk}=(\mathrm{n}-\mathrm{k}-1)=(50-5-1)$ dan pembilang $(\mathrm{k}=5)$ adalah sebesar 2,427.

Berdasarkan Tabel di atas maka dapat dilihat bahwa $\mathrm{F}_{\text {hitung }}$ untuk variabel beban kerja $\left(\mathrm{X}_{1}\right)$ dan disiplin $\left(\mathrm{X}_{2}\right)$ terhadap kinerja $(\mathrm{Y})$ adalah sebesar 6,243, maka $F_{\text {hitung }}$ 
$(6,243)>0,05$ ini berarti bahwa ada pengaruh beban kerja $\left(X_{1}\right)$, displin $\left(X_{2}\right)$ secara bersama-sama terhadap kinerja Awak kapal (Y), sehingga $\mathrm{H}_{0}$ ditolak dan $\mathrm{H}_{\mathrm{a}}$ diterima.

Nilai signifikan (Sig F) adalah sebesar 0,000 yang berarti Sig F $(0,000)<\alpha$ $(0,05)$. Hal tersebut menggambarkan bahwa ada pengaruh yang signifikan beban kerja $\left(\mathrm{X}_{1}\right)$ dan disiplin $\left(\mathrm{X}_{2}\right)$ secara bersama-sama terhadap kinerja Awak kapal (Y).

Tabel 80

Coefficients $^{\mathrm{a}}$

\begin{tabular}{|c|c|c|c|c|c|c|}
\hline \multirow{2}{*}{\multicolumn{2}{|c|}{ Model }} & \multicolumn{2}{|c|}{ Unstandardized Coefficients } & \multirow{2}{*}{$\begin{array}{c}\text { Standardized } \\
\text { Coefficients } \\
\text { Beta } \\
\end{array}$} & \multirow[t]{2}{*}{$t$} & \multirow[t]{2}{*}{ Sig. } \\
\hline & & B & Std. Error & & & \\
\hline \multirow{3}{*}{1} & (Constant) & 8,085 & 4,973 & & 1,626 & 111 \\
\hline & $\mathrm{X} 1$ &,- 157 & 192 & - 101 &,- 817 & 418 \\
\hline & $\mathrm{X} 2$ & , 031 & 247 & ,020 & , 124 & ,902 \\
\hline
\end{tabular}

Sumber : Hasil Pengolahan Data dengan SPSS ver. 2.0

\section{Pengaruh Beban Kerja Secara Parsial Terhadap Kinerja Pegawai}

Berdasarkan hasil perhitungan dengan menggunakan SPSS for windows ver 20, diperoleh nilai koefisien regresi beban kerja adalah sebesar $-0,157$, hal ini menggambarkan bahwa beban kerja $\left(\mathrm{X}_{1}\right)$ mempengaruhi kinerja awak kapal (Y) adalah sebesar $-15,7 \%$, sedangkan nilai $t_{h i t u n g}(-0,817) \leq 0,05$, berarti bahwa ada pengaruh negatif beban kerja terhadap kinerja awak kapal negara Andromeda , maka $\mathrm{H}_{0}$ diterima dan $\mathrm{H}_{\mathrm{a}}$ ditolak. Hal ini didukung pula dengan nilai signifikan (Sig t) pengaruh beban kerja terhadap kinerja awak kapal sebesar 0,418 , yang berarti sig t $(0,418) \geq \alpha(0,05)$, hal tersebut berarti bahwa pengaruh beban kerja terhadap kinerja awak kapal adalah tidak signifikan.

Dari hasil perhitungan di atas menggambarkan bahwa beban kerja tidak memberikan kontribusi yang cukup terhadap kinerja awak KN Andromeda. Ini menggambarkan bahwa beban kerja tidak berpengaruh signifikan terhadap kinerja pegawai. Hal ini dapat dimengerti bahwa pada dasarnya awak kapalmampu mencapai kinerja denga baik, walaupun beban kerja yang diterima cukup banyak awak kapaltetap bekerja secara maksimal karena penghasilan yang mereka terima cukup besar, sehingga awak kapal tetap semangat bekerja. 


\section{Pengaruh Disiplin Secara Parsial Terhadap Kinerja Pegawai}

Berdasarkan hasil perhitungan dengan menggunakan SPSS for windows ver 20, diperoleh nilai koefisien regresi disiplin adalah sebesar 0,031, hal ini menggambarkan bahwa disiplin (X2) mempengaruhi kinerja awak kapal (Y) adalah sebesar 3,1\%, sedangkan nilai thitung $(0,124) \leq 0,05$, berarti bahwa tidak ada pengaruh disiplin terhadap kinerja awak kapal negara Andromeda, maka $\mathrm{H}_{0}$ diterima dan $\mathrm{H}_{\mathrm{a}}$ ditolak. Hal ini didukung pula dengan nilai signifikan (Sig t) pengaruh disiplin terhadap kinerja awak kapalsebesar 0,902 , yang berarti sig $\mathrm{t}(0,902) \geq \alpha(0,05)$, hal tersebut berarti bahwa pengaruh disiplin terhadap kinerja awak kapal adalah tidak signifikan.

Dari hasil perhitungan di atas menggambarkan bahwa disiplin tidak memberikan pengaruh signifikan terhadap kinerja awak KN Andromeda. Dapat dilihat bahwa disiplin kerja pada dasarnya memberikan suatu kontribusi yang kecil terhadap kinerja awak kapal ehingga tidak terlalu signifikan. Hal ini dapat dimaklumi bahwa dengan tingkat disiplin yang tinggi, maka awak kapal akan berusaha mencapai kinerja yang telah ditentukan.

Disiplin kerja merupakan salah satu faktor penentu bagi keberhasilan dan kemajuan dalam mencapai tujuan organisasi. Disipilin disini adalah mengenai disiplin waktu dan disiplin mentaati peraturan yang telah ditetapkan dalam organisasi. Selain itu, disiplin juga berkaitan dengan kepatuhan awak kapalterhadap peraturan-peraturan tertentu, baik yang ditetapkan dari dirinya maupun oleh pihak lain. Awak kapal juga harus memiliki kesadaran sendiri untuk mematuhinya tanpa harus ada paksaan dari orang lain.

\section{SIMPULAN}

Bertolak dari hasil temuan dan analisis data dengan uji statistik, maka dapat diambil kesimpulan sebagai berikut :

1. beban kerja dan disiplin kerja secara bersama-sama berpengaruh positif dan signifikan terhadap kinerja awak KN Andromeda.

2. Beban kerja berpengaruh negatif dan tidak signifikan terhadap kinerja awak awak KN Andromeda.

3. Disiplin berpengaruh positif dan tidak signifikan terhadap kinerja awak awak KN Andromeda. 
Berdasarkan simpulan diatas, maka penulis memberikan saran sebagai berikut :

1. Pimpinan Kantor Distrik Navigasi Kelas I Palembang hendaknya mengevaluasi kembali kinerja pegawai, sehingga lebih meningkatkan kinerja awak kapal sesuai dengan yang diharapkan. Untuk itu, perlu diperhatikan faktor-faktor internal dan ekstrnal yang menunjang sarana dan prasarana kerja termasuk keteladanan dan manajerial. Hal yang tidak kalah pentingnya adalah memberikan reward dan punishment bagi karyawan secara terukur dan adil.

2. Awak KN Andromeda hendaknya tetap bekerja semaksimal mungkin, dan terus berusaha untuk meningkatkan kinerjanya, karena jika kinerja mereka meningkat, dengan harapan penghasilan mereka juga meningkat. Selain itu, jika prestasi kerja mereka meningkat, maka juga akan berpeluang untuk menduduki suatu jabatan.

3. Bagi peneliti yang akan melakukan penelitian lebih lanjut, sebaiknya variabel yang diteliti lebih diperbanyak lagi misalnya menambahkan variabel kualitas kerja, sistem kerja, prestasi kerja, lingkungan kerja atau variabel-variabel lainnya, sehingga diharapkan dapat memperkaya kajian faktor pengaruh terhadap kinerja awak kapal negara Andromeda dan menghasilkan penelitian yang lebih akurat lagi.

\section{DAFTAR PUSTAKA}

Bernardin dan Russel, 2000, Human Resources Management, Mc Graw Hill, New. York

Gomes, F. Cardoso. 2003. Manajemen Sumber Daya Manusia. Penerbit Andi. Yogyakarta.

Husein, Umar. 2005. Riset Sumber Daya Manusia Dalam Organisasi. PT. Gramedia Pustaka Utama. Jakarta.

Hasibuan, Malayu S.P, 2003, Manajemen SDM, Bumi aksara, Jakarta

Herujito, Yayat M. 2001. Dasar-dasar Manajemen. Penerbit PT. Grasindo. Jakarta.

Jaya. 2008. Pengaruh Budaya Organisasi, Disiplin Kerja dan Pengembangan Karier Terhadap Kinerja karyawan Dinas PU Bina Marga Propinsi Jawa Barat. Tesis. Unpad. Bandung

Mangkunegara, Anwar P. 2005. Manajemen SDM Perusahaaan, PT.Remaja Rosdakarya, Bandung

Mahsun, Mohamad, 2006. Pengukuran Kinerja Sektor Publik,. Penerbit BPFE,Yogyakarta.

Mathis, Jhon H. Jackson. 2002. Manajemen Sumber Daya Manusia. Terjemahan Salemba Empat. Jakarta. 
Nugraheni, M. D. 2009. Hubungan Antara Beban Kerja Dengan Tingkat Kelelahan Kerja Pada Operator Unit Spinning IV Ring Frame Shift B PT. APAC Inti Corpora Tahun 2008. Skripsi. Fakultas Ilmu Keolahragaan. Universitas Negeri, Semarang. Tidak diterbitkan.

Sekaran, Uma. 2010. Metodologi Penelitian Untuk Bisnis. Salemba Empat. Jakarta.

Siswanto. H.B. 2006. Pengantar Manajemen. Jakarta: Bumi Aksara

Sulistiani, Ambar Teguh dan Rosidah. 2003. Manajemen Sumber Daya Manusis: Konsep, Teori dan Pengembangan Dalam Konteks Organisasi Publik. Graha Ilmu. Yogyakarta.

Susilawati.2005. Pengaruh Motivasi Kerja dan Disiplin Kerja Terhadap Kinerja Awak kapalpada Badan Penelitian dan Pengembangan Daerah Provinsi Sumatera Selatan. Tesis. MAP Unsri 